\section{Acquired Pure Red Cell Aplasia}

SIR,-May we make the following observation about your article on acquired pure red cell aplasia and its treatment with steroids (6 April, p. 3) ?

A pure red cell aplasia that responded to riboflavine or prednisone has been described in African adults and in children with marasmus and kwashiorkor. ${ }^{1}$ In marasmus and kwashiorkor an erythroid aplasia is frequently present when the children enter hospital in a serious clinical condition, with low total serum proteins, reversed albumin/ globulin ratio, giant pro-erythroblasts in the marrow, but the haemoglobin not grossly reduced. This aplasia is associated with infection and remits spontaneously, or when the infection is treated with antibiotics. Later, when the children are clinically better and their serum proteins are normal, an erythroid aplasia may develop which is not associated with infection, does not remit spontaneously or respond to antibiotics, and has no giant pro-erythroblasts in the marrow. This later aplasia responds to either riboflavine or prednisone, and unless so treated the children frequently die suddenly, either in hospital or when they have been discharged, from what appears to be adrenal insufficiency. About $10 \%-20 \%$ of children with marasmus and kwashiorkor in Kenya develop this erythroid aplasia during the recovery syndrome. It occurs 6 to 16 weeks after the children have been admitted to hospital and will be missed unless their stay is prolonged and frequent serial marrow biopsies are taken over a long period of time. Histological abnormalities in the adrenal cortex, and in serum steroids, have been described in marasmus and kwashiorkor. ${ }^{2-4}$

A similar pure red cell aplasia has now been produced in baboons (Papio anubis) fed on a synthetic diet adequate in calories and all the necessary mineral salts and vitamins except riboflavine. ${ }^{5}$ In children with marasmus and kwashiorkor, and in the baboons, aplasia was judged by the absence of reticulocytes and profound falls in the marrow red cell precursors as estimated cytologically, as well as by depressed marrow activity determined by decreased uptake and plasma clearance of ${ }^{59} \mathrm{Fe} .{ }^{6}$ As in marasmus and kwashiorkor there are histological abnormalities in the adrenal cortex of the riboflavinedeprived baboons, but whether these are associated with derangements in production or metabolism of steroids is being investigated."

In the aplasia of infection the marrow neutrophils are raised, and giant pro-erythroblasts are present, but in aplasia not associated with infection it is the marrow lymphocytes that are increased and giant proerythroblasts are not present. Lane et al. ${ }^{\gamma}$ have produced erythroid aplasia in man by giving a riboflavine-deficient diet supplemented with the antagonist 10-ducityl 7,8 dimethyl iso-alloxazine. Riboflavine-deprived baboons with erythroid aplasia and children with marasmus and kwashiorkor show changes in the urinary excretion of various tryptophan metabolites, such as xanthurenic, anthranilic and kynurenic acids, kynurenine, and 3-hydroxy-kynurenine." In children with erythroid aplasia in marasmus and kwashiorkor the predominant increase is usually in the excretion of anthranilic acid, but in riboflavine-deficient baboons the increase affects xanthurenic acid as well. Other workers have also described an increase in the excretion of anthranilic acid in erythroid aplasia in man, but unlike that in riboflavine-deficient baboons it did not respond to riboflavine, although there was a reduction in the excretion of anthranilic acid.

Corticosteroids are known to affect marrow activity in man and there appears to be an association between the riboflavine deficiency and corticosteroid activity. ${ }^{8}$ In baboon there appears to be a link between riboflavine deficiency, adrenal dysfunction, and erythroid aplasia, which may also exist in the erythroid aplasia of marasmus and kwashiorkor. Some of the erythroid aplasia may indeed be associated with immunological factors. We think, however, that the majority of cases are directly due to congenital adrenal defects, to vitamin deficiency affecting the adrenals, or to hormonal imbalance, as in thymomas.

Since the erythroid aplasia can now be produced in baboons experimentally, the opportunity exists for investigating many aspects of this interesting condition, and the findings may well be applicable to man.We are, etc.

HENRY FOY.

Wellcome Trust Research ATHENA KONDI. Laboratories,
Nairobi, Kenya.

\section{REFERENCES}

Kondi, A., Macdougall, L., Foy, H., Mehta, S. 267.

Leonard, P. J., and MacWilliam, K. M., J. Endocr., 1964, 29, 273.

Foy, H., 'Gillman, T., Kondi, A., and Preston, J. K., Nature (Lond.), 1966, 212, 150. Foy, H., and Kondi, A., Vitamins and Hormones, 1968 , in press. Academic Press Inc., New York.
Kondi, A., Foy, H., and Mbaya, V. Brit. 7. Kondi, A., Foy, H., an

Haemat. 1967, 13, 967.
Foy, H., Kondi, A., Harriss, B. B., and Preston, J. K., Acta haemat. (Basel), 1968, $39,118$. M. A., and Doherty, J., f. clin. Invest., 1964, 43. 357 .

1954, 209, 303

\section{Drugs and Sleep}

SIR,-May I reply to the letters of Dr. A. W. Raffan (4 May, p. 301) and Dr. J. T. Silverstone (20 April, p. 175)?

Dr. Raffan recalls the 1923 observations by MacWilliam, ${ }^{1}$ and it certainly would appear that he saw the blood pressure and heart rate changes characterizing paradoxical sleep periods. ${ }^{2}$ Dr. Raffan refers to effects of nitrazepam. It would seem quite possible that nitrazepam, while suppressing the eye movement and E.E.G. features of paradoxical sleep, could have less effect on blood pressure: the penile erections of paradoxical sleep are said to persist when other features of paradoxical sleep are suppressed by drugs.

My colleagues and I, using electroencephalographic recordings during sleep, and standard statistical tests, demonstrated the distortion of sleep by the slimming drug diethylpropion (30 March, p. 796). Dr. Silverstone's was a critical letter. He considered a report of his own" to be " of greater relevance." He wrote that he found no differences between placebo and diethylpropion as far as sleep was concerned. Unlike ourselves, he made no observations during the course of sleep. He could, in fairness, have mentioned that he also failed to demonstrate any statistically significant differences between placebo and diethylpropion (Tenuate) on calorie intake or weight.

Dr. Silverstone questions our use of 50 mg. diethylpropion. The manufacturers of Tenuate recommend $75 \mathrm{mg}$. in divided doses during the day and another $25 \mathrm{mg}$. in the evening. I believe that the evening brain concentration persisting from the $75 \mathrm{mg}$. would at least equal that caused by the additional $25 \mathrm{mg}$. As I read the literature on dosage we gave a very modest comparative dose of diethylpropion. Had we been stricter then one must suppose that, in the comparison with $40 \mathrm{mg}$. fenfluramine, diethylpropion would have made an even worse showing than it did.

Dr. Silverstone prefers not to be swayed by the four published accounts of diethylpropion dependence we quoted. It is possible that writing from St. Bartholomew's Hospital he may believe all cases of drug dependence get published. I believe it is frequently not the case in the average mental hospital. Even the manufacturers of Tenuate, in their literature, acknowledge other unpublished cases of dependence brought to their notice.

When diethylpropion is taken for slimming, tolerance quickly develops, and its sought-after effects disappear, in contrast to fenfluramine. ${ }^{5}$ Diethylpropion is a pep-pill by day ${ }^{6}$ and, as we showed, distorts sleep by night. It is a drug of dependence, whereas fenfluramine does not appear to be one. It would seem that diethylpropion must soon be regarded as obsolete.-I am, etc.,

\section{University Department of IAN OSWALD. Psychiatry,
Edinburgh 10.}

\section{REFERENCES}

1 MacWilliam, J. A., Brit. med. f., 1923, 2, 1196 A., Morrison, D. F., and Goldfrank, F., f. appl. Physiol., 1964, 19, 417 Ser., 1967, No. 150 , p. 168 .

Silverstone, J. T., and Cleary, T., Clin. Trials f., 1967, 4, 837 .

Lunro, J. P. Frit. med. f., 1966, 2, 624. Duncan, Jonsson, C. O., Sjoberg, L., and Vallbo, S.,
Scand. f. Psychol., 1965, 6, 52 .

\section{Advantages of Fenfluramine}

SIR,-Your “Today's Drugs" article on drugs for depression (23 March, p. 753) included fenfluramine (Ponderax) along with amphetamine derivatives, stating that all have similar side-effects.

We would like to point out that fenfluramine is completely devoid of stimulant properties, in contrast with these other compounds, and therefore cannot be said to have similar side-effects. Current opinion ${ }^{1-3}$ indicates that amphetamine and its stimulant derivatives may no longer hold a place in the treatment of obesity. We feel that fenfluramine can be regarded as replacing these drugs in obesity, as it is demonstrably effective in reducing appetite and has been shown not to have the harmful effects produced by stimulant drugs. - I am, etc.

\section{N. SANTER,}

Director,

\section{Harrow, Middx.}

Munro, J. F., Seaton, D. A., and Duncan, L. J. P., Brit. med. f., 1966, 2, 624.
White, A. G., Beckett, A. H., and Brookes,
L. G., Brit. med. Ұ., 1967, 1, 740.
Brit. med. F., 1967, 3, 159. 